\title{
Effects of Material and Cold Air Temperature Conditions on Safflower Biodiesel Viscosity and Evaluation with Anova/Taguchi
}

\author{
Mustafa Taşyürek, Murat Mirik, Şerafettin Ekinci, and Mustafa Acaroğlu
}

\begin{abstract}
In this paper response surface methodology (RSM) was used to study the transesterification reaction of safflower for biodiesel production. Biodiesel is alternative fuel, with catalyst and alcohols reaction production, from vegetable oils, animal oils and waste fried oils. But there are fuel problems to be solved before biodiesel. These are storage time, storage conditions and cloudy and flow points which have flow peculiarity in the low heats. In this research, physical and chemical properties as a fuel of Safflower Methyl Ester (SME) which are biodiesel fuels are determined. In this research, method of transesterification is employed. Attitudes in storage time and storage conditions of SME are investigated. As a result, SME viscosity figures, according to measured dates, are below 40 Redwood min. at $40^{\circ} \mathrm{C}$. Also the effects of outer temperature and fuel temperature on viscosity were found significant $(P<0.01)$ by the performed variance analysis.
\end{abstract}

Index Terms-Biodiesel, fuel properties, safflower methyl ester, storage, taguchi method.

\section{INTRODUCTION}

Today, society is continuing its intensive search for alternative sources and research for the energy requirements. One of these alternative energy sources are biodiesel. Biodiesel is a renewable and environmentally friendly. However, there are problems of biodiesel fuel. These are storage time, storage conditions, with flow properties at low temperatures, the cloud and pour point. Cloud and pour point are flow properties at low temperatures. One of the biggest technical obstacles of biodiesel is not suitable lack of adequate flow properties especially in winter conditions.

So that the biodiesel in cold climates with high yield point that would adversely affect the availability of fuel. Therefore, this feature should be used with a pour point depressor. An additive used to improve the cold flow properties will affect positively to the degree of crystallization and clogging of the fuel filter.

As biodiesel properties can be affected by environmental conditions. This impact should be known that the circumstances in how. The environmental conditions, especially temperature are an important feature. In addition,

Manuscript received March 17, 2015; revised October 8, 2015.

Mustafa Taşyürek is with Selcuk University, Technology Faculty, Metallurgical and Material Engineering Department, Konya, Turkey (e-mail: mtasyurek@selcuk.edu.tr).

Murat Mirik is with Cumhuriyet University, Sivas Higher Vocational School Sivas, Turkey (e-mail: mmirik@cumhuriyet.edu.tr).

Şerafettin Ekinci and Mustafa Acaroğlu are with Selcuk University, Technology Faculty, Mechanical Engineering Department, Konya, Turkey (e-mail: sekinci@selcuk.edu.tr, muacaroglu@selcuk.edu.tr). storage time and storage features also affect the fuel properties. Klopfenstein [1], has stored to soy methyl ester in steel and plastic containers for 20 months and the peroxide value of the sample stored in steel containers have found that the higher the plastic container.

DuPlesis et al. [2], have examined oxidative stability of the ethyl and methyl ester produced from sunflower oil and during the 90-day test, ethyl and methyl esters were tested by storing in different containers under a variety of experimental conditions. Acaroğlu and Demirbaş [3] have investigated the effect of viscosity and density on flash point in some biodiesel fuel and investigated the methyl esters of safflower, palm, soybean, mustard, nut, and rapeseed. Erdoğan [4] examined the physical properties of vegetable oils whether or not engine fuel and stated that the viscosity is higher.

Taguchi's technique has been popular for parameter optimization in design of experiments (DOE) for decades. Such programs in recent years have begun to be preferred in many different fields of science such as surface hardness measurements [5], biodiesel production optimization [6], [7], image deblurring [8], interrill erosion [9] study. The Taguchi method was adopted as the experimental design methodology, which was adequate for understanding the effects of the control parameters and to optimize the experimental conditions from a limited number of experiments [7]. Buasri et al. [10], obtain biodiesel from oil palm have optimized using the Taguchi method and they have reported on the production temperature and the amount of catalyst. Ganapathy et al. [11] have made the engine performance evaluation of jatropha biodiesel using the Taguchi program. In this study, duration and storage conditions of the biodiesel fuels produced from safflower oil by the transesterification process are investigated the effect on fuel properties of biodiesel and their results were determined.

The biodiesel storage conditions are depends on the fuel temperature, the storage material, storage time and ambient temperature. Instead of performing numerous experimental studies to optimize the process parameters in the Taguchi experimental design, fewer amount of test were sufficient to achieve better conditions of use of methyl ester. The primary advantage of the Taguchi method for optimization is using orthogonal arrays for design to simplify the task of planning experiments greatly.

\section{MATERIALS AND METHODS}

In this study, safflower oil methyl ester and has used as material. The biodiesel reactor is used to safflower methyl 
ester (SME) produce from safflower oil. Methanol $\left(\mathrm{CH}_{3} \mathrm{OH}\right)$ has $99.9 \%$ purity, $0.791 \mathrm{~kg} /$ liter density, $32.04 \mathrm{~g} / \mathrm{mol}$ molecule weight, 64.4-64.7 ${ }^{\circ} \mathrm{C}$ distillation interval. Sodium hydroxide $(\mathrm{NaOH})$ has 40.00 molecule weights, $99.5 \%$ real matter [12].

The aim of the obtaining methyl ester is to prepare accordingly of the catalyst used in reacting vegetable oil and alcohol [12]. Production scheme of biodiesel is shown in Fig. 1.

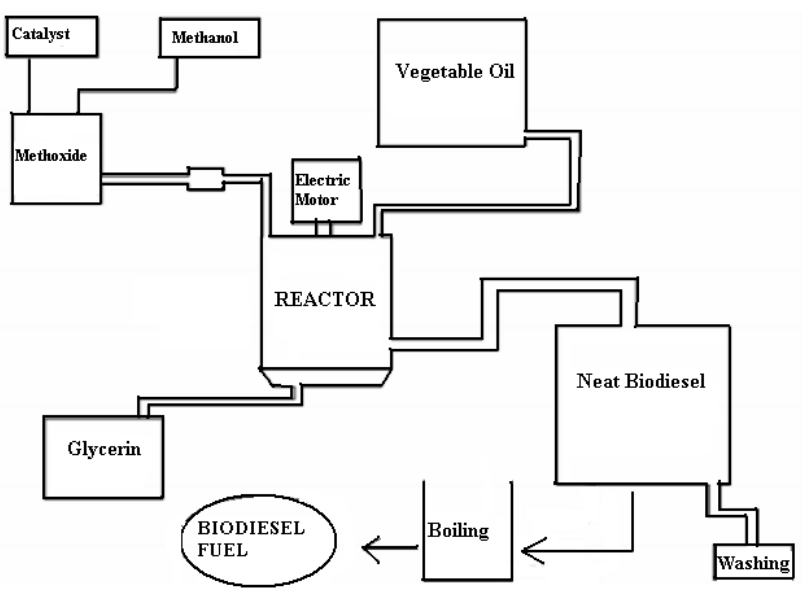

Fig. 1. Production scheme of biodiesel [4], [12], [13].

Safflower oil is placed in the reaction tank after filtration. Biodiesel is heated to $60^{\circ} \mathrm{C}$. Heat treatment of the substances placed in the mixture makes it easier to stir.70 $\mathrm{g}$ of this catalyst was placed into a separate container during heating. The catalyst as $\mathrm{NaOH}$ (sodium hydroxide) was added. Addition of 4 liters of methyl alcohol is added. The resultant final mix is called methoxide. The mixture is mixed at 1000-1500 rev/min. After placing the methoxide tank mixing started immediately. Stirring is continued for $70 \mathrm{~min}$. After the mixing is complete, the glycerin settles to the bottom of the container. After collapse the receiving of biodiesel is started. Separation was performed using a pump. After separation the washing is started. Washing was continued for 3 hours. Boiling temperature was set at $105^{\circ} \mathrm{C}$.

Redwood No. 1 model viscometer was used for measure the fuels viscosities. The fuels put covered in glass bottles, and bottles was protected from sun by means of encircle with aluminum folio and hide at closed environment (in the sunshineless cupboard) in order to determination characteristic at storage conditions of safflower biodiesel (see Fig. 2).

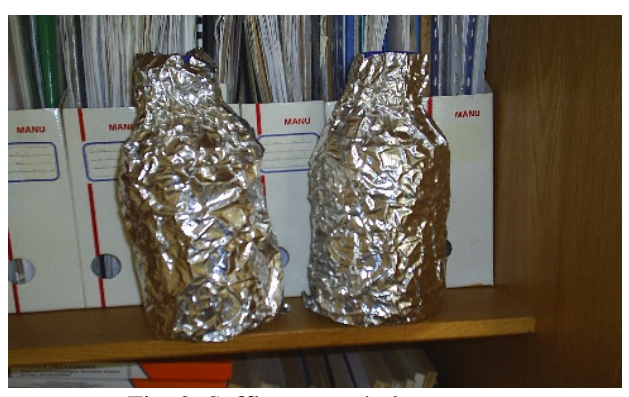

Fig. 2. Safflower methyl ester.

Flash point of safflower was determinate with flash point device which is Koehler trade mark around type. Measures are at least 3 repeat.
The design of experiment used a statistical technique to investigate the effects of various parameters included in experimental study and to determine their optimal conditions. The design of the experiment via the Taguchi method uses a set of orthogonal arrays for performing of the fewest experiments. The Taguchi approach is used for the process optimization of transesterification.

The full factorial experimental parameters with factors and levels involve hundreds of experimental results. This increases the number of experimental runs correspondingly it takes time and requires a very high cost. So, firstly analysis of the material was performed. Three material numbers were reduced to 1 . Later, experiments were conducted on ambient temperature and fuel temperature.

The $\mathrm{S} / \mathrm{N}$ ratio indications can be separated into three groups: the smaller-the-better, the larger-the-better, and the nominal-the-best [14]. This study aimed to optimize the fuel viscosity. Hence, smaller-the-better has been debated to compute the $\mathrm{S} / \mathrm{N}$ ratio.

The authors use the L18 $\left(6^{\wedge} 13^{\wedge} 6\right)$ orthogonal array of the Taguchi method to determine the optimal (A) viscosity of biodiesel and (B) storage materials. In here $\mathrm{A}$ and $\mathrm{B}$ represents viscosity and container material respectively. Also, in B 1, 2, and 3 represents glass, plastic, and metallic material respectively. Also, in $\mathrm{A} 1,2,3,4,5$, and 6 represents temperature of fuel $\left(20^{\circ} \mathrm{C}, 25^{\circ} \mathrm{C} 40^{\circ} \mathrm{C}, 50^{\circ} \mathrm{C}, 65^{\circ} \mathrm{C}, 90^{\circ} \mathrm{C}\right.$ respectively) in Table I and Table II.

TABLE I: DESIGN OF EXPERIMENTS L18 ORTHOGONAL ARRAY

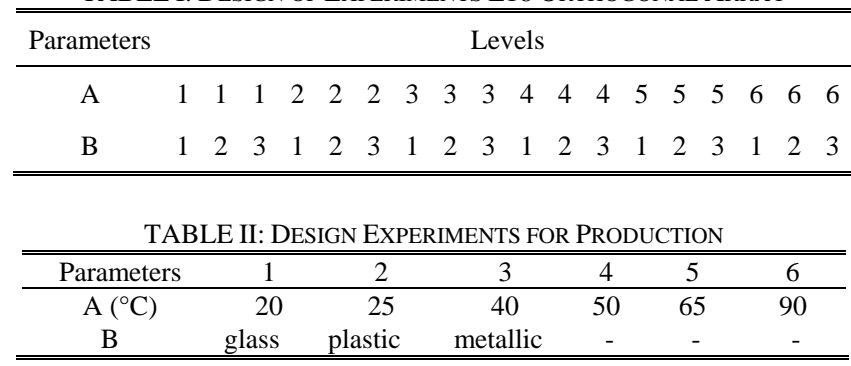

\section{Discussion AND RESUlts}

In this study, nowadays for use in vehicles which have diesel technology, effect of safflower methyl ester (SME) on storage time and fuel characteristic was investigated. The values obtained from biodiesel were compared with the diesel fuel. Comparing the SME based on the diesel is given in Table III. Fuel properties have started to be measured in December. Also, viscosity variation is given in Fig. 3 according to date.

TABLE III: FUEL PROPERTIES OF SME

\begin{tabular}{lcccc}
\hline \hline Fuel Property & Unit & SME & Diesel & EN 14214 \\
\hline Density (at $15{ }^{0} \mathrm{C}$ ) & $\mathrm{kg} / \mathrm{m}^{3}$ & 880 & 838 & $860-900$ \\
Kinematic viscosity & $\mathrm{mm}^{2} / \mathrm{s}$ & 4.02 & 2.4 & $3.50-5.00$ \\
(at $40{ }^{0} \mathrm{C}$ ) & ${ }^{\circ} \mathrm{C}$ & 180 & 64 & $120(\mathrm{~min})$ \\
Flash Point (FP) & -- & 49.8 & 52.1 & 51 \\
Cetane Number & ${ }^{\circ} \mathrm{C}$ & -4 & -6 & - \\
Cloud point (CP) & ${ }^{\circ} \mathrm{C}$ & -6 & -20 & - \\
Pour Point (PP) & ${ }^{\circ} \mathrm{C}$ & -11 & -29 & -- \\
Freezing point & $\mathrm{MJ} / \mathrm{kg}$ & 40.0 & 45.35 & -- \\
HHV & $\mathrm{MJ} / \mathrm{kg}$ & 37.0 & 41.76 & -- \\
LHV & & & & \\
\hline \hline
\end{tabular}

There wasn't a great distinction about dates at the viscosity 
variation in SME. At the same time there wasn't variation on SME's color, after oxidation test which 240 hours and apply on Safflower Methyl Ester. Its color has light yellow. But it always been a risk for oxidation owing to it has high iodine number. The average results of SME's viscosity are given for all temperatures and all container materials in Table IV.

\begin{tabular}{|c|c|c|c|}
\hline Temp. $\left({ }^{\circ} \mathrm{C}\right)$ & glass & plastic & tin \\
\hline 20 & 7,28 & 13,22 & $\begin{array}{c}9,3 \\
2\end{array}$ \\
\hline 25 & 6,78 & 10,39 & $\begin{array}{c}8,6 \\
3\end{array}$ \\
\hline 40 & $\begin{array}{c}4,98 \\
8\end{array}$ & 9,24 & $\begin{array}{c}4,6 \\
8\end{array}$ \\
\hline 50 & 3,31 & 6,74 & 3,4 \\
\hline 65 & $\begin{array}{c}2,68 \\
8\end{array}$ & 5,33 & $\begin{array}{c}2,2 \\
5\end{array}$ \\
\hline 85 & 1,45 & 3,36 & 1,1 \\
\hline 90 & 0,95 & 2,94 & 0,7 \\
\hline
\end{tabular}

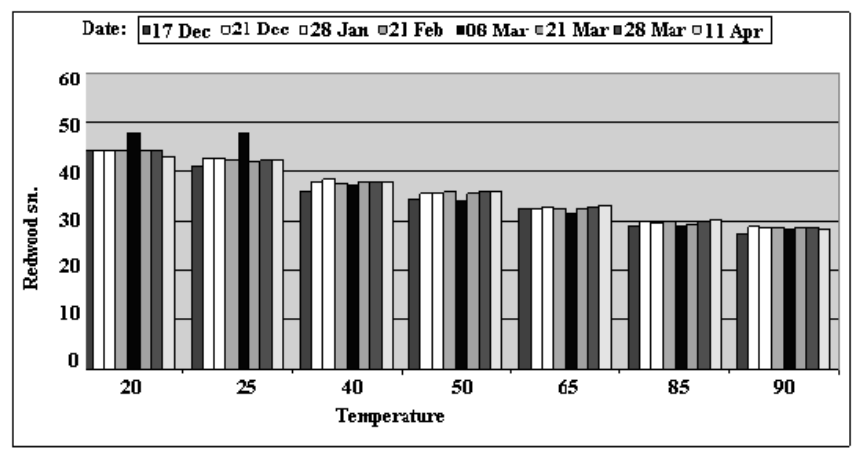

Fig. 3. Variation of AME viscosity according to dates.

\section{DEtermination OF Optimal MATERIAl by TAGUChi METHOD}

The experimental data are compared according to the results estimated in Taguchi program. As shown in Fig. 4 under all conditions, there is a great similarity. This is an indication that could increase the number of tests performed under real conditions and forecast the approach of the experiments.

According to the results; it is seen that plastic material has negative effect on the viscosity. But, the effect of glass and metal are positive. It is known that metallic materials be used as storage container. Not found in the literature, the work on the glass material. Thus, studies were continued for ANOVA about glass material. In addition, $\mathrm{SN}$ ratios for biodiesels container materials and temperatures are shown in Fig.5.

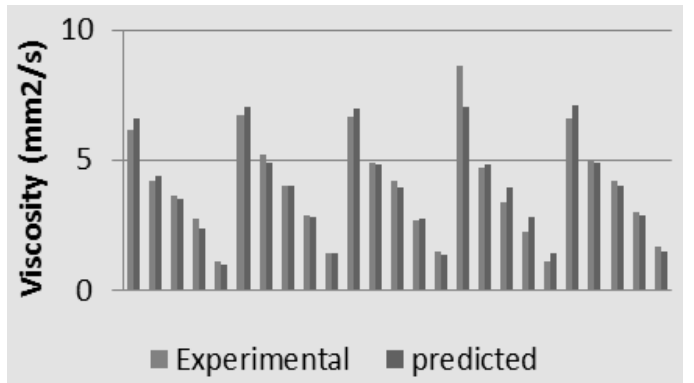

Fig. 4. Comparison of experimental and predicted data.

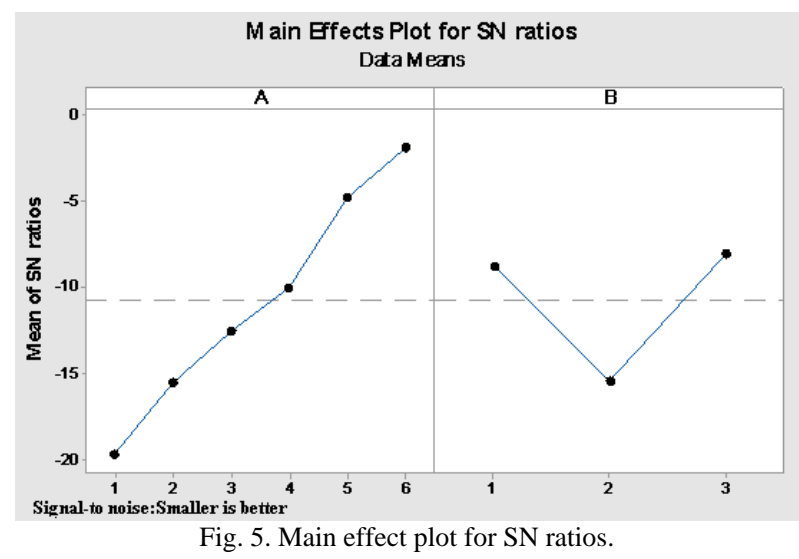

\section{ANALYSIS OF VARIANCE (ANOVA)}

Variance analyses of manipulated variables such as outer temperatures and viscosity measurement temperatures were done in order to determine effects on viscosity of biodiesel from safflower methyl ester. MINITAB 14 software program was used to obtain the results of variance analysis were done via ANOVA module. Then results are given in Table $\mathrm{V}$.

\begin{tabular}{|c|c|c|c|c|}
\hline Source & DF & SS & MS & $F$ \\
\hline Date & 7 & 1,364 & 0,195 & $1,17^{\mathrm{ns}}$ \\
\hline Temperature & 6 & $\begin{array}{c}314,84 \\
5\end{array}$ & 52,474 & $\begin{array}{c}314,02 * \\
*\end{array}$ \\
\hline Error & 42 & 7,018 & 0,167 & \\
\hline Total & 55 & $\begin{array}{c}323,22 \\
7\end{array}$ & & \\
\hline Date 1 & 7 & 68,055 & 9,722 & $12,12 * *$ \\
\hline Temperature 1 & 6 & $\begin{array}{c}630,48 \\
2\end{array}$ & $\begin{array}{c}105,08 \\
0\end{array}$ & $\begin{array}{c}130,98 * \\
*\end{array}$ \\
\hline Error & 42 & 33,696 & 0,802 & \\
\hline Total & 55 & $\begin{array}{c}732,23 \\
4\end{array}$ & & \\
\hline Date & 2 & 48,526 & $\begin{array}{c}24,262 \\
9\end{array}$ & $34,79 * *$ \\
\hline Temperature 2 & 6 & $\begin{array}{c}188,44 \\
4\end{array}$ & $\begin{array}{c}31,407 \\
3\end{array}$ & $45,04 * *$ \\
\hline Error & 12 & 8,368 & 0,6973 & \\
\hline Total & 20 & $\begin{array}{c}245,33 \\
7\end{array}$ & & \\
\hline
\end{tabular}

\section{CONCLUSION}

In this study, once others fuel properties keep an eye, it is certain that AME will be a good biodiesel sources with its storage conditions aspect.

1) Fuel tanks, storing cans or small amount in ready sale point plastic can are not certainly using, for preventing fuels oxidation.

2) In the diesel fuel and biodiesel, if storage conditions don't suitable, viscosity rises in the course of time.

3) Although plastic cans have more sensitive towards oxidation in biodiesel, steel and glass cans less sensitive than these. At the biodiesel should prefer to storage stainless-steel or chromium-nickel cover.

4) The conclusion reveals that container material had greater influence on viscosity. The major conclusion of Taguchi analysis exposes that the results direct to the 
conclusion that combination of factors metallic material-high temperature $\left(90^{\circ} \mathrm{C}\right)$ and glass material-high temperature $\left(90^{\circ} \mathrm{C}\right)$ offer minimum viscosity.

5) The other major conclusion (ANOVA results) reveals that temperature of fuel had greater influence on viscosity.

\section{ACKNOWLEDGMENT}

Data for this study were taken from master's thesis of Mustafa Taşyürek at the Selçuk University.

\section{REFERENCES}

[1] W. E. J. Klopfenstein, "Effect of molecular weights of fatty acid esters on cetane numbers as diesel fuels", Am. Oil Chem. Soc., vol. 62, pp. 1029-1031. 1985.

[2] L. M. Du Plessis, J. B. De Villiers, and W. H. Van der Walt, "Stability studies on methyl and ethyl fatty acid esters of sunflower seed oil," JAOCS, vol. 62, no. 4, pp. 748-752, 1985.

[3] M. Acaroğlu and A. Demirbas, "Relatonships between viscosity and density measurements of biodiesel fuels," Energy Sources, vol. 29, issue 8, pp. 705-712, 2005.

[4] D. Erdoğan, "The use of vegetable oil as fuel in diesel engine," presented at the 13th National Congress of Agricultural Mechanization, Konya, Turkey, 1991.

[5] Ş. Karabulut, "Optimization of surface roughness and cutting force during AA7039/Al2O3 metal matrix composites milling using neural networks and Taguchi method,” Measurement, vol. 66, pp. 139-149, 2015.

[6] H. Karabas, "Biodiesel production from crude a corn (Quercus frainetto L.) kernel oil: An optimisation process using the Taguchi method,” Renewable Energy, vol. 53, pp. 384-388, 2013.

[7] R. Sathish Kumar, K. Sureshkuma, and R. Velraj, "Optimization of biodiesel production from Manilkarazapota (L.) seed oil using Taguchi method," Fuel, vol. 140, pp. 90-96, 2015.

[8] K. Y. Chan, N. Rajakaruna, U. Engelke, I. Murray, and N. Abhayasinghe, "Alignment parameter calibration for IMU using the Taguchi method for image deblurring," Measurement, vol. 65, pp. 207-219, 2015.

[9] F. B. Zhang, Z. L. Wang, and M. Y. Yang, "Assessing the applicability of the Taguchi design method to an interrill erosion study,” Journal of Hydrology, vol. 52, pp. 65-73, 2015.

[10] A. Buasri, P. Worawanitchaphong, S. Trongyong, and V. Loryuenyong, "Utilization of scallop waste shell for biodiesel production from palm oil-optimization using taguchi method,” PCBEE Procedia 8, pp. 216-221, 2014.
[11] T. Ganapathy, K. Murugesan, and R. P. Gakkhar, "Performance optimization of Jatropha biodiesel engine model using Taguchi approach," Applied Energy, vol. 86, pp. 2476-2486, 2009.

[12] M. Taşyürek, "The effects of storage time and conditions on fuel properties in safflower and palm oil biodiesel," M. S. thesis, Institute of Science and Technology, Selçuk Univ., Konya, Turkey, 2005.

[13] M. Çelik, M. Taşyürek, and M. Ünaldı, "A study on the improvement of fuel properties of biodiesel biodiesel fuel specifications," presented at the Symposium Energy Crops and Green Fuels, İzmir, Turkey, 2006.

[14] M. S. Senthil Kumar, N. M. S. Raju, P. S. Sampath, and U. Vivek, "Tribological analysis of nanoclay/epoxy/glass fiber by using Taguchi's Technique," Materials and Design, vol. 70, pp. 1-9, 2015.

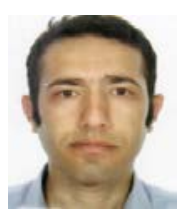

Mustafa Tasyürek was born in 1982, who received his $\mathrm{PhD}$ degree in mechanical education from Selçuk University, Turkey in 2014. From 2005 to present, he is a research assistant with Selçuk University. Currently, he is a research assistant at the Department of Metallurgical and Materials Engineering, Selçuk University, Turkey.

His research interests are biofuels, nanomaterials, nanocomposites and mechanical properties. He is a member of IACSIT.

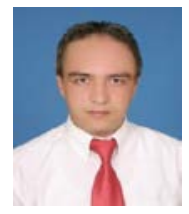

Murat Mirik was born in 1982, who received his master degree in machine training from Selçuk University, Turkey in 2010. Currently, he is a lecturer at the Rail Systems Machine Technology Programme, Cumhuriyet University, Turkey.

His main research interest includes nanocomposite materials. He is a member of IACSIT.

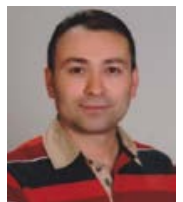

Şerafettin Ekinci is with the Department of Mechanical Engineering, Technology Faulty, Selçuk University, Konya, Turkey. He was born in Sivas, Turkey, 1971, who received his Ph.D in agricultural machineries from Konya, Turkey in September 2011, with major field of study focused on traction mechanics.

His research interests are traction performance, tire and tribology. He is a member of IACSIT.

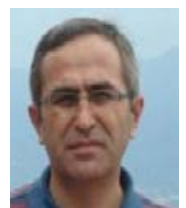

Mustafa Acaroğlu was born in 1962, who is currently a professor at Selçuk University, Faculty of Technology, Department of Mechanical Engineering.

His main research interest includes biofuels. 